\title{
ELOKUVATEORIAN ULOTTUVUUKSISTA
}

Lähikuvan vuoden 2017 viimeinen numero suuntaa katseensa elokuvan teorian ja käytännön laita-alueille ja eri ulottuvuuksiin. Keskiössä ei ole elokuva tarinankerronnan välineenä vaan toisenlaiset tavat käyttää ja ymmärtää elokuvaa välineenä ja teoreettisena koetinkivenä. Numeron artikkelien ja katsausten näkökulmat ovat moninaisia. Vertaisarvioiduissa artikkeleissa pureudutaan Henri Bergsonin filosofiaan, Sergei Eisensteinin ja Jean Epsteinin näkemyksiin neljännestä ulottuvuudesta elokuvassa ja maahanmuuttajataustaisten nuorten tekemiin elokuvaprojekteihin identiteetin rakentamisen välineinä. Katsauksissa tarkastellaan Stan Brakhagen kokeellisia elokuvia, kamerakynäpedagogiikkaa ja Aki Kaurismäen suhdetta Robert Bressoniin. Keskinäisestä erilaisuudestaan huolimatta kaikissa numeron teksteissä pilkahtaa tavalla tai toisella esiin kysymys elokuvavälineen suhteesta ajatteluun.

Aleksi Rennes tarkastelee artikkelissaan Henri Bergsonin filosofian suhdetta elokuvaan. Vaikka ranskalaisfilosofin ajattelu on vaikuttanut keskeisellä tavalla eritoten Gilles Deleuzen elokuvafilosofiaan, Bergsonin omissa kirjoituksissa elokuva välineenä mainitaan vain ohimennen ja silloinkin melko negatiiviseen sävyyn. Bergsonin tapa käsitellä kuvallisuuden, liikkeen ja ajan teemoja kuitenkin ennakoi myöhempiä elokuvatutkimuksen painotuksia. Artikkeli luotaa Bergsonin havaintoteorian näkökulmasta elokuvan kykyä käsitellä subjektiivisen kokemuksen ja materiaalisen maailman välistä suhdetta. Rennes valottaa, miten Bergsonin ajattelu yhtäältä on luonteeltaan syvästi elokuvallista ja miten toisaalta elokuva itsessään näyttäytyy bergsonilaisen filosofian soveltamisena käytäntöön.

Antti Pönnin artikkeli käsittelee neljännen ulottuvuuden teemaa Sergei Eisensteinin ja Jean Epsteinin elokuva-ajattelussa. Sekä Eisenstein että Epstein viittavat elokuvakirjoituksissaan Albert Einsteinin ajatukseen ajasta neljäntenä ulottuvuutena ja pyrkivät lähestymään elokuvan luonnetta sen avulla. Eisenstein pohtii, miten elokuva voisi vaikuttaa katsojan tietoisuuteen. Tähän liittyen hän nostaa esiin elokuvassa taustalle jäävät, mutta katsojan kannalta silti merkitykselliset elementit, jotka hän rinnastaa musiikin yläsäveliin. Yksi tällainen "yläsävelen" elementti on Eisensteinille kuvassa nähtävä liike, jonka hän nimeää neljänneksi ulottuvuudeksi. Myös Epsteinille neljäs ulottuvuus liittyy ajalliseen muutokseen kuvassa. Toisin kuin Eisenstein, Epstein ei suoranaisesti ole kiinnostunut elokuvan vaikutuksesta katsojaan, vaan siitä, miten katsoja kohtaa elokuvassa toisenlaisen ja vieraan havainnon maailmasta, elokuvakoneen tavan "nähdä" ja "ajatella" neljässä ulottuvuudessa. Artikkeli 
nostaa esiin sen, miten sekä Eisensteinilla että Epsteinilla neljännen ulottuvuuden ajatus nivoutuu heidän elokuva-ajatteluunsa sisältyvään kognition kriisiin, jännitteeseen tieteellisyyden ja mystisyyden välillä.

Helena Oikarinen-Jabai tutkii artikkelissaan tapoja, joilla maahanmuuttajataustaiset nuoret käsittelevät kuulumisen ja identiteetin kokemuksiaan. Artikkelin pohjana on tutkimushanke, jossa somalinuoret toteuttivat joukon dokumentaarisia videoita ja radio-ohjelmia ja näin performatiivisesti pohtivat omaa identiteettiään suomalaisessa yhteiskunnassa. Tutkimushankkeen yhtenä lähtökohtana on osallistavuus eli se, että nuoret eivät ole vain tutkimuksen kohteena vaan he toimivat kanssatutkijoina, joilla on keskeinen rooli tulosten tuottamisessa. Tutkimuksessa elokuvan funktiona ei ole kokemuksen representaatio, vaan sen ajattelu ja prosessointi. Tuotetut teokset kyllä välittävät myös tekijöiden kokemuksia toisille, mutta yhtä tärkeä on se performatiivinen prosessi, jossa elokuvat syntyvät. Prosessin myötä nuoret voivat käsitellä, tiedostaa ja uudelleen tulkita esimerkiksi erilaisia kulttuurisia stereotypioita ja asemoida omaa suhdettaan niihin.

Jukka Sihvonen syventää katsauksessaan Stan Brakhagen merkitystä elokuvahistoriassa. Brakhage on nähty1960-luvun alusta lähtien äärimmäisen subjektiivisen elokuvantekijän ruumiillistumana, ovathan hänen kokeelliset elokuvansa vahvasti omaelämäkerrallisia ja henkilökohtaisia. Sihvonen monipuolistaa tällaista rajausta avaamalla näkökulmia siihen, mitä henkilökohtainen ote elokuvan välineeseen Brakhagelle tarkoittaa. Brakhagen teokset pohtivat lähtökohtaisesti kuvan ja kielen välistä suhdetta, jossa kieli ei ole pelkästään ilmaisuväline vaan autonominen ja itsereflektiivinen "olento". Laajemmin ymmärrettynä Brakhagen elokuvat kokeilevat ja koettelevat Sihvosen mukaan sitä, millaiselta valoon, väriin ja liikkeeseen tukeutuva elokuvailmaisu näyttää ja kuulostaa. Elokuva aineineen ja laitteineen on työkalu ihmissilmän näkemis- ja kokemiskykyjen ja -kyvyttömyyksien tutkimiseen.

Aymeric Pantet tarkastelee katsauksessaan Aki Kaurismäen suhdetta Robert Bressoniin. Lähtökohtana on Kaurismäen esittämä tulkinta Bressonista melodraamaelokuvien tekijänä. Tältä pohjalta Pantet pohtii, millä tavoin ja missä määrin Bressonin ja Kaurismäen elokuvat edustavat melodraaman traditiota ja miten Kaurismäki elokuvissaan muokkaa ja ottaa omakseen Bressonin käyttämiä melodraaman elementtejä. Kyse ei kuitenkaan ole vain vaikutteiden arvioinnista, vaan myös sen pohtimisesta, miten Kaurismäen elokuvat omalla tavallaan kommentoivat tai tulkitsevat Bressonia suomalaisesta kontekstista käsin. Kaurismäen tuotanto näyttäytyykin eräänlaisena "tutkimuksena" Bressonista, Bressonin tuotannon ajattelemisena uudelleen.

Ismo Kiesiläinen esittelee katsauksessaan koulumaailman käyttöön kehittämäänsä kamerakynäpedagogiikan mallia. Lähtökohtana Kiesiläisellä on ollut Alexandre Astrucin vuonna 1948 esittämä vaikutusvaltainen ajatus "kamerakynästä" (caméra-stylo). Astrucin kamerakynämetaforan perusajatus oli se, että elokuvakamera voisi olla ajattelun ja sen ilmaisun välineenä yhtä monipuolinen kuin kirjoitettu kieli. Astrucin kamerakynäpohdinnat ovat enemmän suggestiivisia kuin täsmällisiä ja avaavat näin mahdollisuuden monenlaisille tulkinnoille. Tähän mahdollisuuteen Kiesiläinen on tarttunut. Kiesiläisen kamerakynäpedagogiikassa kamera ei ole tarinankerronnan tai taiteellisen ilmaisun väline. Sen sijaan tavoitteena on kertaluonteisesti havainnoida, prosessoida ja visualisoida ilmiöitä, käsitteitä ja oppimissisältöjä yksinkertaisen videolaitteen kuten puhelimen avulla. Näin kamerasta tulee samalla Astrucin kuuluttama ajattelun väline. 

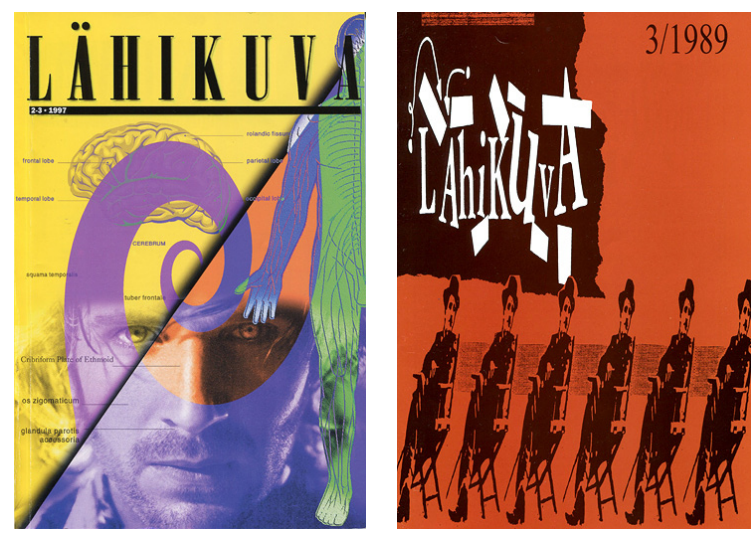

Elokuvateorian ulottuvuudet ovat puhuttaneet Lähikuvassa ennenkin. Arkistojen aarteina julkaisemme kaksi artikkelia. Pasi Nyyssösen vuoden 1997 artikkelissa perehdytään elokuvaan psykologisena ilmiönä Münsterbergin, Eisensteinin ja kognitiopsykologian valossa. Varhaisempaa perua puolestaan on Veijo Hietalan vuoden 1989 artikkeli, jossa etsitään subjektin paikkaa ja mielen kieltä klassisessa elokuvateoriassa, erityisesti formatiivisessa teoriaperinteessä.

Tämän numeron artikkelit ja katsaukset tarjoavat kukin omalla tavallaan uusia näkökulmia myös siihen, mitä elokuva potentiaalisesti voi olla tai miten sitä voidaan tehdä, katsoa ja tulkita toisella tavalla. Tarkastelukohteena ovat siis elokuvateorian ulottuvuudet. Elokuva voi avata uusia näkökulmia maailman, ajallisuuden ja subjektiviteetin filosofiseen tarkasteluun. Se voi olla vaikuttamisen väline tai tuoda todellisuudesta esiin ulottuvuuksia, jotka muutoin jäisivät näkemättä. Sillä voidaan tutkia ja kommentoida toisia elokuvia tai nähdä asioita toisella tavalla. Se voi olla myös käytännöllinen apuväline, jonka avulla voi tutkia omaa identiteettiään tai oppia uusia asioita maailmasta. Sanalla sanoen elokuva ja elokuvateorioiden paljous voivat avata uusia teitä ajattelulle.

Joulukuussa 2017

Antti Pönni ja Tytti Rantanen 